$P$-ISSN : 2623-0534

E-ISSN : 2655-1454

Website Jurnal : https://ejournal.iahntp.ac.id/index.php/satya-widya/index

DOI: $\underline{\text { https://doi.org/10.33363/swjsa.v3i2.477 }}$

\title{
Pola Konsumsi Makanan Satwika Pada Bhakta Di Sri Sri Krishna Balarama Ashram
}

\author{
I Gede Sutana
}

Sekolah Tinggi Agama Hindu Negeri Mpu Kuturan Singaraja

sutanagde@gmail.com

\begin{tabular}{|c|c|}
\hline $\begin{array}{l}\text { Riwayat Jurnal } \\
\text { Artikel diterima : } \\
\text { Artikel direvisi : } \\
\text { Artikel disetujui : }\end{array}$ & \\
\hline $\begin{array}{l}\text { Kata Kunci: } \\
\text { Pola Konsumsi } \\
\text { Makanan Satwika, } \\
\text { Bhakta, } \\
\text { Sri Sri Krishna } \\
\text { Balarama Ashram } \\
\text { Denpasar }\end{array}$ & $\begin{array}{l}\text { Abstrak } \\
\text { Makanan merupakan sarana untuk bertahan hidup. Dalam hal } \\
\text { makanan, manusia memiliki kebudayaan masing-masing mengenai } \\
\text { pola konsumsi makanan. Pada penelitian ini, yang menarik adalah } \\
\text { bhakta di Sri Sri Krishna Balarama Ashram Denpasar memiliki pola } \\
\text { konsumsi makanan tersendiri yang berbeda dengan masyarakat pada } \\
\text { umumnya yang tidak mengkonsumsi makanan yang mengandung } \\
\text { daging, ikan, dan telur. Pola konsumsi makanan ini disebut dengan } \\
\text { pola konsumsi makanan satwika. Adapun maksud penelitian ini } \\
\text { adalah untuk mengetahui pola konsumsi makanan satwika pada } \\
\text { bhakta di Sri Sri Krishna Balarama Ashram Denpasar. Dalam } \\
\text { pengamatan lebih lanjut teori pilihan rasional dan fungsionalisme } \\
\text { struktural menjadi pisau analisis untuk mengungkap pola konsumsi } \\
\text { makanan satwika pada bhakta di Sri Sri Krishna Balarama Ashram } \\
\text { Denpasar. Penelitian ini menggunakan metode kualitatif dengan } \\
\text { melakukan wawancara dan observasi secara langsung terhadap } \\
\text { tokoh-tokoh dan bhakta di Sri Sri Krisna Balarama Ashram } \\
\text { Denpasar. Di samping itu penulis juga melakukan kajian pustaka } \\
\text { terhadap beragam rujukan yang berkaitan dengan lingkup penelitian } \\
\text { khususnya pola konsumsi makanan satwika. Penelitian ini } \\
\text { menghasilkan temuan bahwa, hal yang mendorong bhakta di Sri Sri } \\
\text { Krishna Balarama Ashram menerapakan pola konsumsi makanan } \\
\text { satwika didasari oleh aturan yang berlaku, pilihan rasional bhakta, } \\
\text { dan fungsional terhadap kehidupan baik kehidupan jasmani maupun } \\
\text { rohani. Pola konsumsi makanan satwika menunjukkan lima } \\
\text { komponen yang berlaku diantaranya (1) cara memperoleh bahan } \\
\text { makanan satwika, (2) jenis-jenis bahan makanan satwika, (3) menu } \\
\text { makanan satwika, (4) cara mengolah makanan satwika, dan (5) cara } \\
\text { menghidangkan makanan satwika. Serta implikasi yang diperoleh } \\
\text { dari penerapan pola konsumsi makanan satwika berimplikasi } \\
\text { terhadap fisik, mental dan spiritual. }\end{array}$ \\
\hline
\end{tabular}


Pola Konsumsi Makanan Satwika Pada Bhakta

Di Sri Sri Krishna Balarama Ashram

I Gede Sutana

\begin{tabular}{|c|c|}
\hline $\begin{array}{l}\text { Keyword: } \\
\text { Satwika Food } \\
\text { Consumption } \\
\text { Patterns, } \\
\text { Devotees, } \\
\text { Sri Sri Krishna } \\
\text { Balarama Ashram } \\
\text { Denpasar }\end{array}$ & $\begin{array}{l}\text { Abstract } \\
\text { Food is a means of survival. In terms of food, humans have their } \\
\text { respective cultures regarding food consumption patterns. In this } \\
\text { research, what is interesting is that the bhakta at Sri Sri Krishna } \\
\text { Balarama Ashram Denpasar have their own food consumption } \\
\text { patterns that are different from the general public who do not } \\
\text { consume foods containing meat, fish and eggs. This food } \\
\text { consumption pattern is called the satwika consumption pattern. The } \\
\text { purpose of this research was to determine the pattern of consumption } \\
\text { of satwika food among bhakta at Sri Sri Krishna Balarama Ashram } \\
\text { Denpasar. In further observation, the theory of rational choice and } \\
\text { structural functionalism becomes the tool of analysis to reveal the } \\
\text { consumption patterns of satwika food among bhakta at Sri Sri } \\
\text { Krishna Balarama Ashram Denpasar. } \\
\text { This research used a qualitative method by conducting interviews } \\
\text { and direct observation of the figures and bhakta at Sri Sri Krisna } \\
\text { Balarama Ashram Denpasar. In addition, the authors also conducted } \\
\text { a literature review of various references related to the scope of } \\
\text { research, especially satwika food consumption pattern. This } \\
\text { research results in the finding that, what motivates the bhakta of Sri } \\
\text { Krishna Balarama Ashram to apply the satwika food consumption } \\
\text { pattern is based on the prevailing rules, rational choice of bhakta, } \\
\text { and functional towards both physical and spiritual life. The pattern } \\
\text { of consumption of satwika food shows five components that apply } \\
\text { including (1) how to obtain satwika food ingredients, (2) types of } \\
\text { satwika food ingredients, (3) satwika food menu, (4) how to process } \\
\text { satwika food, and (5) how to serve satwika food. As well as the } \\
\text { implications obtained from the application of the satwika } \\
\text { consumption pattern have implications for physical, mental and } \\
\text { spiritual. }\end{array}$ \\
\hline
\end{tabular}

Pendahuluan

Kehidupan modern menunjukkan pilihan dalam menentukan pola konsumsi makanan yang sangat beragam. Hal ini juga ditandai dengan keberadaan masyarakat di Negara berkembang yang meniru kebiasaan Negara Barat yang dianggap sebagai refleksi pola hidup modern, termasuk juga kebiasaan pola makannya. Hal itu didahului pada Negara maju, yaitu Amerika dan Eropa Barat, kemudian berpengaruh ke Asia termasuk Asia Tenggara (Maysuhara, 2009:93). Dewasa ini ada kecenderungan masyarakat di Negara berkembang untuk menyantap makanan yang mengandung daging dan hasil olahannya. Hal ini mengikuti

Satya Widya : Jurnal Studi Agama Vol. 3 No. 22020 


\section{Pola Konsumsi Makanan Satwika Pada Bhakta}

Di Sri Sri Krishna Balarama Ashram

\section{Gede Sutana}

kebiasaan masyarakat di Negara maju, seperti mudahnya mendapatkan ayam goreng cepat saji dan kentang goreng. Di samping itu hasrat hidup lebih modern dan gaul jika makan di kedai maupun restauran cepat saji (Kariadi, 2009: 81). Hal ini ditunjukkan dari Hasil Survei Sosial Ekonomi Nasional mengungkapkan bahwa, terdapat peningkatan rata-rata konsumsi kalori per kapita sehari dari tahun 2009 sampai dengan 2010 sebanyak 15,1\%. Hal itu terjadi, baik di perkotaan maupun di perdesaan. Pulau Bali juga mengalami hal yang sama. Kenaikannya adalah sebesar 28,7 \%, lebih tinggi daripada angka nasional. Dari tahun 2009 sampai dengan 2010 juga terjadi peningkatan konsumsi daging (Susenas, 2010: 196).

Pola hidup modern khusunya dalam konsumsi makanan, tidak serta-merta dapat membawa perubahan kearah yang lebih baik, hal ini ditandai dengan semakin maraknya jenis-jenis penyakit pada pola hidup modern, seperti kanker, diabetes, hipertensi, dan obesitas yang membawa manusia untuk memikirkan pola hidup sehat sehingga dapat mengurangi resiko munculnya penyakit-penyakit tersebut. Salah satu pola hidup sehat itu adalah suatu cara dengan jalan meminimalkan konsumsi makanan olahan dan berpengawet yang selama ini begitu mendominasi (Prima, 2009: iii-iv). Pola pengaturan kesehatan secara

Hindu tertuang dalam ilmu Ayurveda. Ayurveda adalah ilmu pengetahuan tentang upaya manusia untuk memperoleh kesehatan dan umur yang panjang. Untuk mencapai hal tersebut, dalam ilmu Ayurveda diajarkan 3 pilar pokok yang harus dilakukan oleh umat manusia untuk menjaga kesehatan, ialah: ahara, nidra, vihara. Dalam ahara diajarkan tentang bagaimana cara melakukan diet yang seimbang. Makan dan minum sesuai kebutuhan, baik dalam kuantitas maupun kualitas untuk menjaga kesehatan (Nala, 2001: 23-72).

Di Bali, khususnya umat Hindu sejak dulu telah memiliki tradisi mengolah makanan dengan resep-resep tradisional Bali, sebagaimana hidangan khas Bali seperti lawar, sate, dan lainnya yang mengandung bahan daging. Namun berbeda dengan masyarakat pada umumnya yang mengkonsumsi daging maupun makanan olahan, Di Kota Denpasar ada komunitaskomunitas spiritual yang memiliki pola konsumsi makanan yang tidak mengkonsumsi daging. Pola konsumsi ini disebut dengan pola konsumsi makanan satwika.

Menurut ilmu Ayurveda alam raya ini (bhuana agung) menyediakan berbagai jenis makanan yang dapat dikelompokan sesuai kandungan tri guna-nya menjadi makanan yang 


\section{Pola Konsumsi Makanan Satwika Pada Bhakta}

Di Sri Sri Krishna Balarama Ashram

\section{Gede Sutana}

bersifat rajasika, tamasika, dan satwika. Dari ketiga sifat makanan tersebut, makanan yang memiliki fungsi paling baik untuk kesehatan manusia adalah makanan yang bersifat satwika (Nala, 2001: 94-97). Pola konsumsi makanan satwika ini belum banyak dikenal oleh masyarakat luas, termasuk masyarakat Hindu di Bali. Pola konsumsi makanan satwika hanya populer khusus di kalangan kelompok-kelompok spiritual. Makanan satwika ini terdiri dari bahan pangan nabati yang diolah dan dikonsumsi dengan baik, serta didoakan sebelum diolah dan dikonsumsi (Acarya, 2005: 2-8).

Penerapan pola konsumsi makanan satwika di Kota Denpasar menjadi kebiasaan sehari-hari para penekun spiritual khususnya bhakta di Sri Sri Krishna Balarama Ashram Denpasar. Di ashram ini sudah lama menerapkan pola konsumsi makanan satwika, yaitu sejak tahun 1991. Walaupun terdapat berbagai jenis makanan yang dijual di rumah makan yang ada di Kota Denpasar sebagaimana layaknya kehidupan kota yang dijajaki tempat untuk membeli dan mengkonsumsi makanan cepat saji, serta kehidupan masyarakat yang cenderung modern, tetapi pada kenyataannya bhakta di Sri Sri Krishna Balarama Ashram tetap menerapkan pola konsumsi makanan satwika. Dalam penelitian ini, pola konsumsi makanan yang diterapkan oleh bhakta di Sri Sri Krishna Balarama Ashram Denpasar adalah pola konsumsi makanana satwika. Pola makanan satwika merupakan pola makan yang makanannya bersumber dari bahan pangan nabati. Penerapan pola konsumsi makanan satwika merupakan salah satu aturan yang wajib dijalankan oleh bhakta di Sri Sri Krishna Balarama Ashram. Hal ini perlu ditelusuri lebih lanjut untuk dapat mempelajari dan memahami kehidupan bhakta di Sri Sri Krishna Balarama Ashram terkait dengan pola konsumsi makanan satwika baik penerapannya, pola konsumsi, dan implikasi dari pola konsumsi makanan satwika. Tujuan dari penelitian ini adalah untuk mendeskripsikan alasan bhakta di Sri Sri Krishna Balarama Ashram menerapkan pola konsumsi makanan satwika, mendeskripsikan pola konsumsi makanan satwika serta implikasi dari penerapan pola konsumsi makanan satwika di Sri Sri Krishna Balarama Ashram Denpasar, sehingga dapat dijadikan sebuah metode dalam penerapan pola konsumsi makanan satwika sehingga berimplikasi terhadap fisik, mental, dan spiritual. 
Pola Konsumsi Makanan Satwika Pada Bhakta

Di Sri Sri Krishna Balarama Ashram

I Gede Sutana

\section{Metode}

Penelitian pola konsumsi makanan satwika pada bhakta di Sri Sri Krishna Balarma Ashram Denpasar merupakan jenis penelitian kualitatif. Data kualitatif diperoleh dengan cara observasi dan interview mendalam dengan pengelola dan bhakta di Sri Sri Krishna Balarama Ashram Denpasar. Instrumen penelitian yang digunakan sebagai alat bantu seperti: wawancara dengan menggunakan pedoman wawancara, handphone untuk mengambil foto dan merekam wawancara. Penelitian ini menggunakan teknik purposive sampling sehingga data yang diperoleh lebih representatif karena langsung memperoleh data dari narasumber yang kompeten dibidangnya. Teknik pengumpulan data dari penelitian ini yaitu: (1) observasi, (2) wawancara, dan (3) studi kepustakaan. Data yang diperoleh dianalisis secara deskriptif kualitatif, dan disajikan secara deskriptif-naratif.

\section{Hasil}

1. Penerapan Pola Konsumsi Makanan Satwika Pada Bhakta di Sri Sri Krishna Balarama Ashram

Penerapan pola konsumsi makanan satwika pada bhakta di Sri Sri Krishna Balarama Ashram Denpasar didorong oleh beberapa hal. Sebagaimana pada umumnya manusia, bhakta adalah makhluk rasional. Kerasionalan inilah menjadi tolak-ukur untuk menilai sesuatu sebagai informasi. Informasi yang kian mudah untuk diakses, termasuk informasi dalam bidang agama, spiritual, begitupula dengan makanan sebagai unsur kesehatan

Wawancara dengan Mataji Puspasara Devi dan Prabu Manmohan Dasa, yang merupakan bhakta di Sri Sri Krishna Balarama Ashram, mengatakan alasan menerapkan pola konsumsi makanan satwika sebagai berikut.

"Kami berdua merupakan pasangan suami istri yang sudah menjadi bhakta sejak masa-masa awal ashram ini didirikan. Awalnya kami tidak terbiasa dengan aturan pola konsumsi makanan satwika. Di dalam proses pembelajaran di ashram, kami menyadari bahwa pola konsumsi makanan satwika ini sangat penting bagi seorang bhakta karena bermanfaat bagi fisik, mental, dan spiritual. Aturan pola konsumsi makanan satwika ini membuat pola makan kami menjadi lebih teratur. Aturan pola konsumsi makanan satwika di Sri Sri Krishna Balarama mengatur tentang bagaimana cara memperoleh makanan satwika hingga sampai cara mengkonsumsinya" (Wawancara, 21 Juni 2017). 


\section{Pola Konsumsi Makanan Satwika Pada Bhakta}

Di Sri Sri Krishna Balarama Ashram

\section{Gede Sutana}

Hal yang sama juga disampaikan oleh Koordinator Sri Sri Krishna Balarama Ashram, Prabu Sahadeva Dasa. Beliau menyampaikan sebagai berikut.

"Kita di ashram memang ada aturan mengenai pola konsumsi makanan satwika. Tetapi selain karena aturan, para bhakta juga berpikir secara rasional sebelum melaksanakan aturan atau ajaran yang diajarkan di ashram. Bhakta meyakini secara rasional, menerapkan pola konsumsi makanan satwika merupakan pilihan yang tepat bagi bhakta yang ingin meningkatkan kualitas spiritualnya, selain itu juga baik untuk mental dan kesehatan fisik. Oleh karena itu, makanan satwika merupakan makanan yang tepat bagi seorang bhakta karena dapat menunjang kesehatn fisik, mental, dan spiritual. Sehingga pola konsumsi makanan satwika ini diterapkan oleh bhakta di Sri Sri Krishna Balarama Ashram” (Wawancara, 26 Juni 2017)

Hal senada disampaikan oleh Pimpinan Sri Sri Krishna Balarama Ashram, Guru Sri Sriman Ida Waisnawa Pandita Damodara Pandit Dasa. Beliau menyampaikan mengapa bhakta di Sri Sri Krishna Balarama Ashram menerapkan pola konsumsi makanan satwika dijelaskan sebagai berikut.

"Saya sebagai pendiri Sri Sri Krishna Balarama Ashram Denpasar mewajibkan bhakta di Ashram mengikuti aturan-aturan sebagai bhakta, salah satunya mengenai aturan pola konsumsi makanan satwika. Dalam menerapkan pola konsumsi makanan satwika di ashram, saya berpedoman pada ajaran kitab suci Bhagawadgita, maupun kitab-kitab suci Hindu lainnya. Tetapi dalam pelaksanaannya, bhakta akan melalui proses panjang untuk bisa melaksanakan aturan ini. Tentunya mereka perlu proses adaptasi untuk bisa melaksanakan aturan ini dengan baik. Aturan, pilihan rasional dan fungsional dari pola konsumsi makanan satwika merupakan 3 hal yang melandasi bhakta dalam menerapkan pola konsumsi makanan satwika. Penerapan pola konsumsi makanan satwika ini bertujuan untuk meningkatkan kesehatan fisik, mental, dan membantu latihan spiritual seorang bhakta. Jika mereka menerapkan pola konsumsi makanan satwika ini dengan benar, niscaya kebahagiaan jasmani dan rohani akan diperoleh oleh bhakta" (Wawancara, 26 Juni 2017).

\section{Pola Konsumsi Makanan Sattwika Pada Bhakta di Sri Sri Krishna Balarama Ashram 2.1 Cara Memperoleh Bahan Makanan Satwika}

Bahan makanan yang tergolong satwika bisa didapatkan dengan beberapa cara. Dari hasil wawancara dengan Prabu Sahadeva Dasa yang merupakan koordinator bhakta yang bertugas memasak makanan di ashram, menjelaskan cara memperoleh bahan makanan satwika sebagai berikut. 


\section{Pola Konsumsi Makanan Satwika Pada Bhakta}

Di Sri Sri Krishna Balarama Ashram

\section{Gede Sutana}

"Bahan makanan satwika untuk konsumsi di Sri Sri Krishna Balarama Ashram bisa diperoleh dari warung, pasar tradisional, pasar swalayan, dan juga di toko yang khusus menjual bahan makanan satwika, seperti di toko Satvika Bhoga yang terletak di jalan Hangtuah Denpasar. Tapi terkadang pada perayaan hari suci di ashram, para bhakta membawa bahan-bahan makanan yang diperoleh dari hasil berkebun atau bertani oleh bhakta itu sendiri. Untuk dana membeli bahan-bahan makanan satwika ini diperoleh dari uang kas atau dana punia bhakta anggota Sri Sri Krishna Balarama Ashram. Jika dana yang digunakan untuk membeli bahanbahan makanan satwika diperoleh dengan cara yang tidak baik (mencuri, korupsi, dan lainnya) maka bahan makanan yang dibeli tersebut tidak akan bersifat satwika" (wawancara, 10 Juli 2017).

\subsection{Jenis Bahan Makanan Satwika}

Makanan satwika di Sri Sri Krishna Balarama Ashram Denpasar menggunakan bahan-bahan alami yang berasal dari tumbuh-tumbuhan (nabati). Makanan jenis vegetarian sebagian besar merupakan makanan satwika. Penjelasan ini sesuai dengan yang dikatakan oleh Prabu Sahadeva Dasa. Beliau mengatakan jenis bahan makanan satwika di Sri Sri Krishna Balarama Ashram adalah sebagai berikut.

"Makanan jenis vegetarian sebagian besar merupakan makanan satwika. Bahanbahan makanan satwika di Sri Sri Krishna Balarama Ashram, diantaranya:

(1) padi-padian (beras merah dan beras putih),

(2) segala jenis kacang-kacangan,

(3) umbi-umbian (singkong, kentang, talas, ubi),

(4) sayuran hampir semuanya satwika kecuali jamur,

(5) buah-buahan (apel, mangga, pisang, alpukat, melon, semangka, belimbing, kelapa, pir, anggur, dan strawberry)

(6) Minuman seperti air mineral, teh, susu (susu segar maupun susu olahan kedelai),

(7) bumbu sederhana (madu, garam, gula tebu, gula aren, jahe, kunyit, lengkuas, adas, daun salam, daun jeruk, daun jinten, cabai, dan tulasi, terkadang menggunakan tepung).

Makanan satwika di Sri Sri Krishna Balarama Ashram tidak mengandung daging, ikan, telur, bawang merah, bawang putih, jamur, makanan yang mengandung alkohol dan bumbu penyedap rasa olahan pabrik" (wawancara 10 Juli 2017).

\subsection{Menu Makanan Satwika}

Berbeda dengan menu makanan pada umumnya, menu makanan satwika tidak mengandung daging, ikan, dan telur. Semua bahan-bahan yang digunakan adalah bahan- 


\section{Gede Sutana}

bahan nabati. Walaupun semuanya bahan pangan nabati, kandungan gizi dan porsi makanan cukup untuk memberikan tenaga kepada tubuh sehingga tubuh dapat melaksanakan aktivitas dengan normal. Hasil wawancara dengan Prabu Sahadeva Dasa, Beliau menjelaskan menu makanan satwika di Sri Sri Krishna Balarama Ashram sesuai dengan penjelasan di atas. Lebih jelasnya Beliau menjelaskan sebagai berikut.

"Menu makanan satwika di Sri Sri Krishna Balarama Ashram bervariasi setiap harinya, guna memperoleh manfaat yang maksimal dari makanan yang dikonsumsi. Beberapa menu makanan yang sering dikonsumsi diantaranya:

(1) Nasi: nasi beras putih, tetapi terkadang juga nasi beras merah

(2) Sayur: Sayur urab, sayur berkuah (soup), diolah dari bahan dasar sawi putih, sawi hijau, bayam, terong, kangkung, kubis, jagung muda, mentimun, daun singkong, wortel, kentang, lobak, bunga kol, brokoli, pare, kacang panjang dan daun kelor.

(3) Lauk: serundeng, kacang goreng, dan kerupuk, tahu dan lauk yang menyerupai daging, yang dibuat dari bahan dasar gluten, tepung beras, tepung terigu, tepung tapioka.

(4) Buah segar: berbagai jenis buah yang masih segar, seperti: apel, pisang, melon, semangka, pepaya, alpukat, mangga, manggis, jeruk, pir, anggur, strawberry, dan buah kelapa.

(5) Minuman: air mineral, teh, jus dari buah-buahan, susu (susu murni dan susu kedelai).

Untuk bhakta yang masih pemula, masih diperbolehkan mengkonsumsi makanan yang menyerupai daging. Tapi seiring semakin lamanya proses belajar di ashram, bhakta hendaknya bisa mengendalikan diri dan pikiran untuk mengurangi makanan yang menyerupai daging" (wawancara 10 Juli 2017).

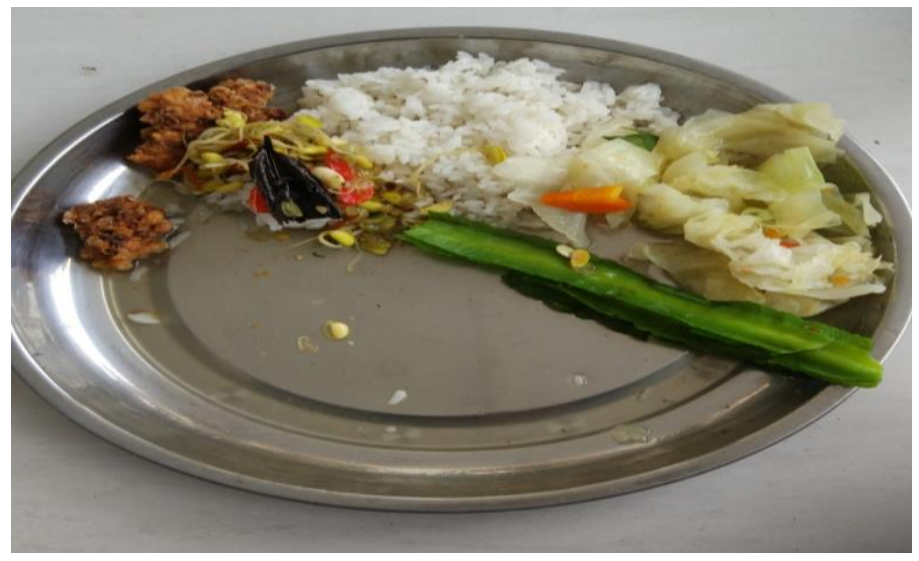

Gambar 1. Menu makanan satwika di Sri-Sri Krishna Balarama Ashram 


\section{Pola Konsumsi Makanan Satwika Pada Bhakta}

Di Sri Sri Krishna Balarama Ashram

\section{Gede Sutana}

Sumber: Dokumentasi Pribadi

\subsection{Cara Mengolah Makanan Satwika}

Berbeda dengan cara mengolah makanan pada umumnya, cara mengolah makanan satwika di Sri Sri Krishna Balarama Ashram Denpasar tidaklah boleh sembarangan, agar makanan yang diolah memberikan dampak positif bagi yang mengkonsumsinya. Untuk mengolah/memasak makanan satwika di Sri Sri Krishna Balarama Ashram, haruslah seorang bhakta yang sudah didiksa dan ditunjuk langsung oleh Guru Pandita. Prabu Sahadeva Dasa selaku koordinator bhakta yang bertugas memasak menjelaskan sebagai berikut.

"Untuk mengolah/memasak makanan satwika di Sri Sri Krishna Balarama Ashram, haruslah seorang bhakta yang sudah didiksa dan ditunjuk langsung oleh Guru Pandita. Sebelum memulai proses memasak makanan satwika, dapur dan peralatan untuk memasak harus bersih. Selain itu bhakta yang memasak juga harus membersihkan dirinya (mandi) terlebih dahulu sebelum memasak. Pada saat memasak bhakta tidak boleh mengobrol atau bercanda, bhakta hendanya melantunkan lagu-lagu kerohanian atau melantunkan mantram gayatri dan menyebut nama Tuhan Sri Krishna. Proses mengolah makanan sama pada umumnya dengan masyarakat, seperti nasi dikukus, sayur, diolah dengan cara direbus, serundeng dan tahu dan terkadang kerupuk diolah dengan cara digoreng, tapi tahu juga bisa direbus bersama dengan sayur. Sementara buah-buahan bisa dikonsumsi langsung setelah dicuci dengan bersih, bisa juga dibuat jus. Teh dibuat dengan cara diseduh, sementara susu dan air putih dikonsumsi dengan cara diminum langsung. Kegiatan memasak ini dilakukan 3 kali di ashram. Jika proses memasak telah selesai, bhakta wajib membersihkan dapur dan membersihkan alatalat perlengkapan yang digunakan untuk memasak. Sebelum dikonsumsu makanan dipersembahkan kepada arca yang ada di Sri Sri Krishna Balarama Ashram (wawancara, 10 Juli 2017).

Penjelasan di atas sesuai dengan yang disampaikan oleh Guru Pandita. Beliau menjelaskan secara spesifik mengenai langkah-langkah mengolah makanan satwika di Sri Sri Krishna Balarama Ashram. Lebih lanjut dijelaskan sebagai berikut.

"Cara mengolah makanan satwika di Sri Sri Krishna Balarama Ashram adalah sebagai berikut:

(1) Nasi: beras merah atau beras putih dibersihkan terlebih dahulu, kemudian dimasak dengan cara dikukus.

(2) Sayuran: Berbagai jenis sayur mayur dipilih yang masih segar, kemudian dicuci bersih, selanjutnya dimasak dan. Sayur biasanya diolah dengan cara di rebus, terkadang ditumis. Memasak sayur dengan menggunakan bumbu rempah sederhana. 


\section{Gede Sutana}

(3) Lauk pauk: Lauk pauk yang sering dibuat adalah serundeng yang diolah dari bahan dasar kelapa yang diparut, dan biasanya ditambah kacang-kacangan. Pengolahannya dengan cara digoreng dengan menggunakan sedikit minyak. Sementara lauk seperti tahu, kerupuk, dan olahan dari tepung biasanya dikonsumsi pada perayaan hari raya suci di ashram, karena dikonsumsi oleh bhakta pemula.

(4) Buah-buahan: buah-buahan dikonsumsi dengan cara diolah menjadi jus atau dikonsumsi secara langsung.

(5) Minuman: minuman yang sering dikonsumsi di ashram yaitu air, teh, jus buah, dan terkadang susu sapi murni.

Tapi yang membedakan cara pengolahan makanan di ashram dengan di tempat lain ialah: yang mengolahnya tidak boleh sembarangan orang, diolah dengan penuh rasa damai dan cinta kasih sambil melantunkan mantram maupun nyanyian rohani” (wawancara, 10 Juli 2017).

\subsection{Menghidangkan dan Mengkonsumsi Makanan Satwika}

Di Sri Sri Krishna Balarama Ashram ada aturan yang harus dilaksanakan oleh bhakta dalam menghidangkan dan mengkonsumsi makanan satwika. Penjelasan di atas sesuai dengan yang disampaikan oleh Prabu Sahadeva Dasa, Beliau menyampaikan sebagai berikut.

"Setelah selesai masak, makanan dihidangkan di atas wadah yang bersih. Sebelum dikonsumsi makanan didoakan terlebih dahulu dan dipersembahkan pada semua altar/arca yang ada di Sri Sri Krishna Balarama Ashram, setelah itu baru bisa dikonsumsi. Kualitas makanan mempengaruhi kualitas pikiran. Jika sebelum makan, mempersembahkan makanan terlebih dahulu makanan tersebut kepada Tuhan maka makanan tersebut menjadi prasadam (Anugrah Tuhan) dan akibatnya segala ketidak murnian dalam makanan akan dihilangkan. Ini membantu pembersihan pikiran secara berangsur-angsur dari ketidakmurnian atau kekotoran yang disebut mala. Waktu mengkonsumsi makanan satwika di Sri Sri Krishna Balarama Ashram, ada perbedaan antara bhakta yang sudah senior dengan bhakta yang masih anak-anak dan bhakta yang pemula. Bhakta yang sudah dewasa atau senior biasanya mengkonsumsi makanan satwika dua kali sehari (siang dan malam) atau bahkan sekali sehari pada perayaan hari-hari suci di ashram. Hal ini berhubungan dengan latihan sadhana (spiritual) yang mereka lakukan. Bagi bhakta yang masih pemula, bisa makan sampai tiga kali sehari (pagi, siang, malam) karena mereka masih dalam fase penyesuaian diri. Sementara bagi bhakta anak-anak juga diperbolehkan makan hinga tiga kali sehari (pagi, siang, malam) karena mereka masih dalam fase aktif yang memerlukan banyak energi untuk beraktifitas. Pada saat mengkonsumsi makanan satwika, bhakta sebaiknya duduk dengan tenang dan terlebih dahulu berdoa sebelum memulai proses makan. Pada saat makan, makan 


\section{Pola Konsumsi Makanan Satwika Pada Bhakta}

Di Sri Sri Krishna Balarama Ashram

\section{Gede Sutana}

harus bersama-sama tidak boleh sendiri-sendiri, akan tetapi bhakta laki-laki dan perempuan tidak duduk berdampingan agar pikiran terfokus" (wawancara, $10 \mathrm{Juli}$ 2017).

\section{Implikasi Pola Konsumsi Makanan Satwika Terhadap Bhakta di Sri Sri Khrishna}

\section{Balarama Ashram Denpasar}

Makanan satwika yang berbahan dasar nabati sering dikaitkan dengan kesehatan. Kesehatan memiliki nilai yang sangat mahal harganya saat ini. Hal di atas sesuai dengan yang disampaikan oleh Prabu Jana Mohini Dasa dan Prabu Siwa Nataraja Dasa. Menurut mereka, pola konsumsi makanan satwika memberikan implikasi terhadap kesehatan fisiknya. Lebih jelasnya mereka mengatakan sebagai berikut.

"Makanan satwika merupakan makanan yang menyehatkan bagi tubuh. Dahulu sebelum menerapkan pola konsumsi makanan satwika, saya terbisa mengkonsumsi makanan yang mengandung daging dan makanan berpengawet lainnya. Pada suatu ketika saya mengetahui bahwa ada keturunan sakit diabetes di keluarga saya. Sejak saat itu saya menerapkan pola pola konsumsi makanan satwika. Setelah saya menerapkan pola makan ini, hingga kini kadar gula darah saya masih dalam batas normal" (wawancara 9 Juli 2017).

Penjelasan di atas didukung oleh Prabu Sadhu Vaisnawa Dasa. Beliau menyampaikan bahwa dengan menerapkan pola konsumsi makanan satwika membuatnya mudah berkonsentrasi saat melakukan meditasi, pikiran menjadi terpusat serta emosi menjadi stabil. Ia menjelaskan sebagai berikut.

"Makanan satwika merupakan salah satu faktor yang dapat meningkatkan mental dan spiritual seseorang. Dahulu sebelum menjadi bhakta dan menerapkan pola konsumsi makanan satwika, saya sangat sulit mengendalikan pikiran ketika bermeditasi. Namun setelah menjadi bhakta dan menerapkan pola konsumsi makanan satwika, saya lebih mudah memfokuskan pikiran, dan melakukan meditasi. Selain itu pikiran juga menjadi tenang dan emosi dengan sangat mudah dikendalikan. Saya juga lebih bisa menumbuhkan kesadaran pada diri serta menumbuhkan rasa cinta kasih di dalam diri” (Wawancara, 9 Juli 2017).

Hal serupa juga dikatakan oleh Prabu Dinabandu Dasa yang merupakan seorang bhakta di Sri Sri Krishna Balarama Ashram. Beliau berpendapat sebagai berikut.

"Mengkonsumsi makanan satwika setiap hari sangat baik bagi perkembangan mental dan spiritual. Dengan mengkonsumsi makanan satwika kita akan memiliki kesadaran diri yang tinggi. Selain itu, kita menjadi lebih mudah dalam 


\section{Pola Konsumsi Makanan Satwika Pada Bhakta}

Di Sri Sri Krishna Balarama Ashram

\section{Gede Sutana}

mengendalikan pikiran, perkataan, dan perbuatan serta menumbuhkan rasa cinta kasih dalam diri. Dengan semua hal positif tersebut, para bhakta akan lebih mudah dalam meningkatkan spiritual dan rasa bhakti kepada Tuhan. Dengan demikian, secara perlahan kesadaran diri, rasa bhakti dan kualitas spiritual bhakta akan berkembang dengan baik" (Wawancara 9 Juli 2017).

Pimpinan Sri Sri Krishna Balarama Ashram, Guru Sri Sriman Ida Waisnawa Pandita Damodara Pandit Dasa juga berpendapat sesuai dengan penjelasan di atas. Beliau menyampaikan implikasi pola konsumsi makanan satwika terhadap bhakta sebagai berikut.

"Makanan satwika memang memiliki banyak manfaat, diantaranya untuk spiritual, fisik, dan mental. Banyak bhakta yang datang kepada saya untuk sekedar berdiskusi maupun untuk menyampaikan apa yang mereka rasakan setelah menerapkan pola konsumsi makanan satwika yang kita terapkan di ashram. Dari segi kesehatan banyak dari bhakta yang merasa badannya lebih segar setelah menerapkan pola konsumsi makanan ini setelah lebih dari setahun. Selain itu mereka juga jarang atau hampir tidak ada menderita sakit yang berat seperti hipertensi, diabetes, jantung, obesitas, apalagi kanker. Untuk bhakta perempuan, mereka mengaku bahwa siklus haidnya berlansung lancar dan tidak terganggu setelah menerapkan pola konsumsi makanan satwika ini. Mungkin masih lebih banyak lagi yang bhakta rasakan, tapi alangkah baiknya ini bisa diterapkan oleh masyarakat umum sehingga manfaatnya tidak hanya sebatas wacana dari bhakta Sri Sri Krishna Balarama Ashram yang menerapkannya saja" (wawancara 9 Juli 2017)

\section{Pembahasan}

\section{Penerapan Pola Konsumsi Makanan Satwika Pada Bhakta di Sri Sri Krishna Balarama Ashram}

Pengaruh sosial budaya dalam masyarakat memberikan peranan penting dalam mencapai derajat kesehatan yang baik. Perkembangan sosial budaya dalam masyarakat merupakan suatu tanda bahwa masyarakat dalam suatu daerah tersebut telah mengalami suatu perubahan dalam proses berfikir. Perubahan sosial dan budaya bisa memberikan dampak positif maupun negatif. Kebudayaan atau kultur dapat membentuk kebiasaan dan respons terhadap kesehatan. Karena itulah penting bagi tenaga kesehatan untuk tidak hanya mempromosikan kesehatan, tapi juga membuat mereka mengerti tentang proses terjadinya suatu penyakit dan bagaimana meluruskan keyakinan atau budaya yang dianut hubungannya dengan kesehatan. (Kurniajaya, 2013: 3) 


\section{Pola Konsumsi Makanan Satwika Pada Bhakta}

Di Sri Sri Krishna Balarama Ashram

\section{Gede Sutana}

Dalam menerapkan suatu hal atau membuat suatu keputusan, ada hal-hal yang mempengaruhi keputusan manusia, termasuk bhakta di Sri Sri Krishna Balarama Ashram. Berdasarkan hasil wawancara yang diperoleh dalam penelitian ini, ada 3 hal yang mendasari bhakta untuk menerapkan pola konsumsi makanan satwika, diantaranya: aturan, pilihan rasional dan fungsional dari makanan satwika tersebut.

Manusia sebagai makhluk sosial yang hidup dengan saling ketergantungan satu sama lain. Dalam proses kehidupan ini, manusia diikat oleh berbagai aturan atau norma-norma yang berlaku dalam suatu kelompok masyarakat. Berbagai aturan dibuat sesuai dengan kebutuhan dan budaya yang berlaku guna membuat hidup masyarakat lebih teratur, termasuk dalam hal mengkonsumsi makanan. Dalam mengkonsumsi makanan juga terdapat aturanaturan yang harus ditaati oleh setiap individu di daerah tertentu, yang mencerminkan tingkah laku sesuai dengan budaya yang berlaku di daerah atau wilayah tertentu. Begitu juga dengan keberadaan Ashram Sri Sri Krishna Balarama Denpasar yang memiliki aturan tertentu dalam hal mengkonsumsi makanan.

Ketika sudah menjadi bhakta di Sri Sri Krishna Balarama Ashram Denpasar, seseorang yang menjadi bhakta wajib mengikuti aturan-aturan sebagai bhakta yang diterapkan di Sri Sri Krishna Balarama Ashram Denpasar. Aturan ini berlaku untuk semua bhakta yang ada di Ashram maupun dirumah masing-masing bhakta. Aturan ini diterapkan dengan tujuan memperoleh manfaat dari pola konsumsi makanan satwika (ISKCON, 2006: 59-63).

Selain aturan, pilihan rasional juga mendasari alasan bhakta dalam menerapkan pola konsumsi makanan satwika. Pilihan rasional mendasari pembuatan keputusan setiap individu. Begitu juga terhadap bhakta di Sri Sri Krishna Balarama Ashram Denpasar. Sebagaimana pada umumnya manusia, bhakta adalah makhluk rasional. Kerasionalan inilah menjadi tolak-ukur untuk menilai sesuatu sebagai informasi. Informasi yang kian mudah untuk diakses, termasuk informasi dalam bidang agama, spiritual, begitupula dengan makanan sebagai unsur kesehatan.

Hal ini didasarkan sebagaimana makanan satwika diyakini memiliki manfaat yang lebih baik daripada makanan pada umumnya yang berbahan dasar bahan pangan hewani dan 


\section{Pola Konsumsi Makanan Satwika Pada Bhakta}

Di Sri Sri Krishna Balarama Ashram

\section{Gede Sutana}

bahan pangan olahan. Suhardana (2010: 25) menguraikan tentang makanan satwika yang mengandung unsur sattwam untuk dapat mengontrol dan memurnikan pikiran, sehingga makanan satwika sangat membantu bhakta dan penganut spiritual lainnya dalam melakukan latihan spiritual. Hal ini juga ditunjukkan oleh para Rsi dan Brahmana pada jaman dahulu yang selalu mengatur makanan satwika untuk menyucikan sifat sattwam-nya. Makanan satwika yang jenisnya berupa pangan nabati dan harganya relatif lebih murah dibandingkan dengan bahan makanan yang berbahan daging atau ikan.

Seperti yang telah dijelaskan di atas, bahwa bhakta di Sri Sri Krishna Balarama Ashram merupakan sekumpulan orang yang melakukan tindakan berdasarkan rasionalitas. Bhakta menunjukkan kerasionalannya ketika terjadi proses pemikiran dan perenungan yang berkelanjutan, sehingga terjadi transformasi pada dirinya. Ketika berbicara tentang makanan, tentunya terdapat berbagai macam jenis makanan khususnya di Kota Denpasar. Di dalam menerapkan pola konsumsi makanan satwika, bhakta membuat keputusan berdasarkan pilihan rasional. Menurut bhakta, mereka memandang bahwa makanan satwika baik dikonsumsi untuk peningkatan kualitas spiritual, dan tentunya juga berpengaruh terhadap kesehatan mental dan fisik, serta tidak terlepas daripada efesien secara ekonomis harga dari bahan-bahan makanan satwika.

Disamping aturan dan pilihan rasional, ternyata fungsi dari makanan satwika ini juga mempenggaruhi bhakta dalam menerapkan pola konsumsi makanan satwika. Berdasarkan hasil wawancara dengan bhakta dan pimpinan di Sri Sri Khrishna Balarama Ashram Denpasar dikatakan bahwa pola konsumsi makanan satwika ini berfungsi bagi kesehatan fisik, mental dan Spiritual.

Makanan satwika yang berbahan dasar nabati sering dikaitkan dengan kesehatan. Kesehatan memiliki nilai yang sangat mahal harganya saat ini. Tubuh ini harus terus dijaga dan dirawat agar tetap dalam kondisi sehat. Bahan nabati yang dikonsumsi menghasilkan mutu protein yang tidak kalah dengan daging. Kacang-kacangan seperti kedelai, sayursayuran, dan buah-buahan segar mengandung zat anti oksidan, fitokimia, serat, mineral, dan berbagai vitamin yang mampu melawan kanker dan meningkatkan sistem imun tubuh. Penyakit-penyakit berat seperti penyakit kanker, jantung, diabetes, hipertensi, stroke, 


\section{Pola Konsumsi Makanan Satwika Pada Bhakta}

Di Sri Sri Krishna Balarama Ashram

\section{Gede Sutana}

diabetes, dan radang usus dipengaruhi oleh pola hidup dan pola makan yang kurang tepat (Budiyasa, 2016: 100).

Makanan satwika ditinjau dari segi kesehatan sangatlah baik. Dalam Bhagawadgita XVII. 8 disebutkan bahwa, makanan satwika merupakan makanan yang memperpanjang hidup, memberikan tenaga, kekuatan, kesehatan, kebahagiaan, suka cita, makanan yang rasanya manis, lunak, mengandung berbagai zat makanan dan rasanya enak adalah makanan satwika yang dikonsumsi oleh individu yang menginginkan untuk meningkatkan sifat sattwam-nya. Perlu diketahui bahwa kemurnian dan kesucian makanan dapat menyucikan pikiran. Makanan seperti ini cocok bagi seorang bhakta yang ingin mencapai kesucian ilahi (Radhakrishna, 2009: 414). Makanan satwika di Sri Sri Krishna Balarama Ashram Denpasar secara fungsional mengarah kepada kesehatan fisik, mental, dan spiritual sebagaimana pengakuan daripada bhakta. Karena hal inilah bhakta di Sri Sri Krishna Balarama Ashram menerapkan pola konsumsi makanan satwika.

Berdasarkan uraian di atas, aturan, pilihan rasional, dan fungsional dari pola konsumsi makanan satwika mendukung bhakta dalam melakukan latihan spiritual. Oleh karena itu, ketiga hal ini merupakan alasan yang mendasari bhakta di Sri Sri Krishna Balarama Ashram dalam menerapkan pola konsumsi makanan satwika.

\section{Pola Konsumsi Makanan Sattwika Pada Bhakta di Sri Sri Krishna Balarama Ashram 2.1 Cara Memperoleh Bahan Makanan Satwika}

Berdasarkan data yang diperoleh dari hasil wawancara dengan narasumber diketahui bahwa bahan makanan satwika untuk konsumsi di Sri Sri Krishna Balarama Ashram diperoleh dari warung, pasar tradisional, pasar swalayan, dan juga di toko yang khusus menjual bahan makanan satwika, serta hasil pertanian dan perkebunan dari para bhakta. Untuk dana membeli bahan-bahan makanan satwika ini diperoleh dari uang kas atau dana punia bhakta anggota Sri Sri Krishna Balarama Ashram. Jika dana yang digunakan untuk membeli bahan-bahan makanan satwika diperoleh dengan cara yang tidak baik (mencuri, korupsi, dan lainnya) maka bahan makanan yang dibeli tersebut tidak akan bersifat satwika.

Makanan satwika dipilih dengan baik, yaitu memilih makanan yang masih segar yang diperoleh dengan cara memetik langsung dari pohonnya atau membelinya dari pasar. Bahan 


\section{Pola Konsumsi Makanan Satwika Pada Bhakta}

Di Sri Sri Krishna Balarama Ashram

\section{Gede Sutana}

makanan yang digunakan sebaiknya bervariasi, agar mengandung berbagai nutrisi dan gizi yang diperlukan oleh tubuh. Menurut Fracassi dan Paul Urbani (2001: 63) jika bahan makanan dipilih atau diperoleh dengan cara yang tidak baik seperti mencuri, makanan bahan makanan tidak lagi bersifat satwika.

Makanan satwika merupakan makanan yang diperoleh dengan cara yang baik serta didominasi oleh karakter satwam dimana jika dikonsumsi akan menghasilkan suatu efek positif seperti membuat pikiran menjadi tenang, jernih, metabolisme tubuh seimbang dan dapat menyehatkan tubuh. Makanan satwika menjadi salah satu unsur yang mendasar untuk menjadi seorang yogi atau bhakta karena sangat menunjang usaha untuk pembersihan baik jasmani maupun rohani (Prima, 2009: 62).

Budiyasa dalam penelitiannya menjelaskan bahwa makanan dikatakan satwika jika: (1) bahan makanan diperoleh dengan cara yang baik, artinya tidak mencuri dan dana untuk membelinya diperoleh dengan cara yang baik, serta bahan makanan harus bersih secara fisik (tidak ada yang busuk). (2) Makanan diolah dengan baik, artinya makanan diolah menggunakan alat-alat yang bersih dan di dapur yang bersih, serta dimasak dengan perasaan bahagia (tidak memikirkan hal-hal negatif). (3) Makanan dikonsumsi dengan baik, artinya makanan yang sudah selesai diolah harus didoakan dahulu sebelum dikonsumsi, sehingga dapat menumbuhkan unsur satwam dalam diri (Budiyasa, 2016: 143).

Tata cara memperoleh bahan makanan satwika mempengaruhi sifat dan kualitas makanan. Makanan yang diperoleh dengan cara yang baik akan memberikan implikasi yang baik pula bagi diri yang mengkonsumsinya. Sedangkan makanan yang diperoleh dengan cara yang tidak baik, akan memberikan implikasi yang tidak baik pada yang mengkonsumsi.

\subsection{Jenis Bahan Makanan Satwika}

Berdasarkan hasil wawancara dengan narasumber, pola makanan satwika di Sri Sri Krishna Balarama Ashram bersumber dari jenis pangan nabati. Pola konsumsi makanan ini berbeda dengan pola makanan pada umumnya yang mengandung daging, ikan, telur, dan berbagai jenis makanan olahan lainnya. Makanan jenis vegetarian sebagian besar merupakan makanan satwika. Prima (2009: 41-48) mengatakan bahwa jenis-jenis makanan satwika diantaranya: sayur mayur, buah segar, kacang-kacangan, biji-bijian, padi-padian, umbi-

Satya Widya : Jurnal Studi Agama Vol. 3 No. 22020 


\section{Pola Konsumsi Makanan Satwika Pada Bhakta}

Di Sri Sri Krishna Balarama Ashram

\section{Gede Sutana}

umbian, madu, air, gula tebu, teh, kopi, susu murni, bumbu masak yang ringan seperti cabe, jahe, kunyit, merica, minyak goreng, dan garam dalam takaran yang kecil agar makanan tetap satwika.

Kurniajaya (2013: 43-44), dalam penelitian yang telah dilakukannya menjelaskan bahwa jenis-jenis makanan satwika adalah bahan-bahan makanan yang berasal dari tumbuhtumbuhan dan tidak mengandung bawang merah, bawang putih, daging, ikan, dan telur. Lebih lengkap dijelaskan jenis-jenis bahan makanan satwika diantaranya: padi-padian (beras), sayuran, buah-buahan segar, umbi-umbian, kacang-kacangan, dan bumbu ringan seperti gula, madu, garam, minyak kelapa, merica, cabe, jahe, kunyit, kencur dan lengkuas. Jenis bahan makanan satwika tidak mengandung daging, ikan, dan telur.

Bahan makanan satwika merupakan bahan makanan berjenis pangan nabati. Satvic (2007: 72) mengatakan bahwa buah-buahan, sayur-sayuran, umbi-umbian yang masih segar, yang dikonsumsi dalam jumlah mencukupi dan dipelihara tanpa bantuan pupuk dan bahan kimia lainnya adalah makanan satwika yang paling baik. Susu mentah segar dari sapi yang dipelihara dengan kasih sayang dan bijak adalah minuman yang sangat satwika. Susu yang dipasteurisasi adalah tamasika, bukan satwika. Kacang-kacangan, beras, gandum dan bijibijian adalah makanan yang satwika secara alami. Minyak wijen, minyak kelapa, minyak zaitun adalah minyak yang baik. Bumbu-bumbuan yang termasuk satwika seperti jinten, adas, jahe, dan kunyit.

Hal yang sama juga dikemukakan oleh Saraswati (2014:45) yang menyatakan bahwa makanan satwika terdiri dari biji-bijian, padi-padian, sayur mayur, susu murni, umbi-umbian, bumbu ringan tanpa bawang merah dan bawang putih yang dimasak dengan penuh rasa kasih. Jika makanan ini disimpan dalam waktu lama makan makanan ini tidak lagi satwika.

Berdasarkan uraian di atas dan hasil wawancara dengan narasumber, diketahui bahwa jenis bahan makanan satwika di Sri Sri Krishna Balarama Ashram, diantaranya berjenis padipadian (beras merah, beras putih), umbi-umbian padi-padian (beras merah dan beras putih), segala jenis kacang-kacangan, umbi-umbian (singkong, kentang, talas, ubi), sayuran hampir semuanya satwika kecuali jamur, buah-buahan (apel, mangga, pisang, alpukat, melon, semangka, belimbing, kelapa, pir, anggur, dan strawberry) Minuman yang dikonsumsi 


\section{Pola Konsumsi Makanan Satwika Pada Bhakta}

Di Sri Sri Krishna Balarama Ashram

\section{Gede Sutana}

diantaranya: air mineral, teh, susu (susu segar maupun susu olahan kedelai), bumbu sederhana seperti: madu, garam, gula tebu, gula aren, jahe, kunyit, lengkuas, adas, daun salam, daun jeruk, daun jinten, cabai, dan tulasi, terkadang menggunakan tepung.

\subsection{Menu Makanan Satwika}

Secara umum, menu makanan yang akan dikomsumsi harus mengadung unsur nutrisi dan gizi yang diperlukan oleh tubuh, seperti karbohidrat, protein, mineral, lemak, dan vitamin Makanan yang sehat merupakan makanan yang unsure gizi yang diperlukan oleh tubuh. Berbeda dengan menu makanan pada umumnya, menu makanan satwika tidak mengandung daging, ikan, dan telur. Semua bahan-bahan yang digunakan adalah bahan-bahan nabati. Walaupun semuanya bahan pangan nabati, kandungan gizi dan porsi makanan cukup untuk memberikan tenaga kepada tubuh sehingga tubuh dapat melaksanakan aktivitas dengan normal. Dari hasil wawancara dengan narasumber dalam penelitian ini dijelaskan bahwa menu makanan satwika di Sri Sri Krishna Balarama Ashram Denpasar terdiri dari nasi, sayur, lauk pauk, buah, dan minuman.

Nasi merupakan makanan pokok bagi mayoritas masyarakat Indonesia. Nasi berbahan dari beras yang dihasilkan oleh tanaman padi (oryza sativa). Beras mengandung karbohidrat yang berfungsi sebagai sumber energi untuk beraktifitas bagi tubuh. Cara pengolahannya mula-mula beras dicuci bersih, setelah itu dikukus. (Sudjati dan Laila, 2004: 80). Nasi di Sri Sri Krishna Balarama Ashram ada dua macam, yaitu nasi dari beras putih dan nasi dari beras merah.

Sayuran dan buah-buahan merupakan komponen penting dalam pola makan satwika. Kebanyakan sayuran dan buah-buahan rendah lemak, semuanya bebas kolesterol. Sayuran dan buah-buahan merupakan sumber vitamin, mineral, juga fitokemikal. Selain itu, kandungan air dan zat gizinya sangat tinggi. Umumnya sayuran dan buah-buahan mengandung protein, vitamin, mineral, serat, dan karbohidrat. Beberapa diantaranya bahkan mengandung zat antioksidan, antibakteri, antijamur, maupun zat anti racun. Sayuran biasanya diolah dengan cara direbus, ditumis, maupun dikonsumsi masih segar. Sedangkan buah 


\section{Pola Konsumsi Makanan Satwika Pada Bhakta}

Di Sri Sri Krishna Balarama Ashram

\section{Gede Sutana}

dikonsumsi dengan diolah menjadi jus atau dikonsumsi langsung (Shiilabhadrananda, 2010: 44-45).

Dari penjelasan tersebut di atas dapat diketahui bahwa menu makanan satwika terdiri dari nasi, sayur, lauk pauk, buah, dan minuman yang bersumber dari olahan bahan nabati tanpa daging ikan, telur, dan bumbu-bumbu berpenyedap atau olahan pabrik.

\subsection{Cara Mengolah Makanan Satwika}

Makanan yang dikonsumsi manusia merupakan sumber pikiran, yang juga memberikan pangan pada pikiran, dan mengembangkannya. Setelah dicerna, bagian makanan yang paling kasar dikeluarkan sebagai kotoran, bagian yang halus menjadi darah dan daging, sedangkan yang terhalus membentuk pikiran. Tubuh fisik dan otak merupakan bagian terpenting yang telah dianugerahkan guna mencapai tingkat kesempurnaan, untuk menjaga kemurnian dan kesehatan tubuh serta pikiran yang bersih, seseorang harus mengolah, mengkonsumsi makanan sehat dan bergizi (Kusuma, 2012:82).

Secara umum, cara mengolah bahan makanan yang hendak dimasak sebaiknya telebih dahulu dicuci dengan air mengalir untuk membersihkan bakteri yang menempel pada bahan makanan tersebut. Untuk memasak bahan makanan yang mengandung vitamin larut air, seperti vitamin B dan C sebaiknya proses memasaknya tidak menggunakan banyak air agar vitaminnya masih berada pada bahan makanan yang sedang diolah. Sedangkan jika harus memasak dengan cara menumis, menggoreng, atau memanggang sebaiknya gunakan sedikit minyak dan waktu mengolahnya jangan terlalu lama agar kandungan vitamin yang ada pada bahan makanan tersebut tidak rusak. Hidangkan dan konsumsi makanan selagi hangat. Jika ingin menyimpannya, simpannya pada wadah yang tertutup rapat agar makanan tidak cepat basi (Widuri, 2013: 173-175).

Menurut Wibawa (2012:98) orang yang memasak makanan satwika haruslah memiliki pikiran yang suci dan dengan hati yang murni. Pada zaman dahulu para Brahmana hanya makan makanan yang mereka siapkan sendiri, dengan demikian perasaan mental dan kesuciannya tetap terjaga dan terjamin. Bila engkau mempekerjakan tukang masak, maka 


\section{Pola Konsumsi Makanan Satwika Pada Bhakta \\ Di Sri Sri Krishna Balarama Ashram}

\section{Gede Sutana}

hanya Tuhan saja yang tahu berapa besar kemurnian, pikiran suci yang dimiliki oleh tukang masak tersebut. Pikiran-pikiran yang tidak suciinilah yang mempengaruhi pikiran anda.

Cara pengolahan bahan makanan satwika bervariasi, ada yang dikukus, direbus, digoreng, dan dimakan mentah. Dalam pembuatan sayura, sebaiknya direbus dan dikukus, hanya sedikit yang ditumis. Pembuatan lauk pauk pengolahannya dengan cara dikukus dan digoreng. Jika menggoreng makanan jangan menggunakan banyak minyak dan waktu menggorengnya jangan terlalu lama. Bahan lainnya seperti buah-buahan biasanya langsung dikonsumsi mentah dan kadang diolah menjadi jus. Pengolahan makanan satwika tidak memerlukan waktu yang lama, karena semua bahan makanan merupakan bahan nabati yang sangat mudah diolah. Selain menggunakan bahan yang alami, proses pengolahan makanan juga menentukan hasil makanan yang akan dikonsumsi. Oleh karena itu, dalam proses pengolahan makanan, bhakta yang mengolah diharapkan dalam keadaan senang, damai baik lahir dan batin agar menghasilkan makanan yang baik bagi kesehatan jasmani maupun rohani (Kurniajaya, 2014: 48).

Sementara Fracassi dan Paul Urbani (2001: 63-68) menyatakan bahwa mengolah makanan satwika harus didasari dengan rasa kasih sayang agar makanan yang kita akan konsumsi memberikan efek positif terhadap tubuh. Kebersihan merupakan hal yang perlu diperhatikan dalam mengolah makanan satwika. Semua alat dan bahan yang digunakan harus dibersihkan terlebih dahulu agar bebas dari kuman atau bakteri penyebab penyakit. Rasa kasih dan sayang juga diperlukan dalam mengolah makanan satwika agar hasil yang diperoleh setelah mengkonsumsi makanan bersifat positif. Hindari berpikiran dan berkata yang negatif saat mengolah makanan satwika. Sebelum memulai memasak hendaknya didahului dengan berdoa kepada Tuhan, agar makanan yang kita olah bermanfaat untuk kesehatan kita. Pengolahan makanan satwika sebaiknya diolah dengan cara direbus atau dikukus dan hindari mengolah dengan cara menggoreng, menumis, atau memanggang.

Dari uraian di atas diketahui bahwa tata cara mengolah makanan satwika di Sri Sri Krishna Balarama Ashram tidaklah boleh sembarangan. Cara mengolah makanan satwika di asharm berbeda dengan cara mengolah makanan pada umumnya. Hal ini bertujuan agar makanan yang diolah memberikan dampak positif bagi yang mengkonsumsinya. Selain itu, 


\section{Pola Konsumsi Makanan Satwika Pada Bhakta}

Di Sri Sri Krishna Balarama Ashram

\section{Gede Sutana}

yang boleh untuk mengolah/memasak makanan satwika di Sri Sri Krishna Balarama Ashram, haruslah seorang bhakta yang sudah didiksa dan ditunjuk langsung oleh Guru Pandita.

\subsection{Menghidangkan dan Mengkonsumsi Makanan Satwika}

Menghidangkan dan mengkonsumsi makanan satwika juga tidak boleh sembarangan. Ada tahapan-tahapan yang harus dilaksanakan sebelum mengkonsumsi makanan satwika, yang terpenting adalah, sebelum mengkonsumsi makanan satwika, makanan terlebih dahulu dipersembahkan kepada arca yang ada di Sri Sri Krishna Balarama Ashram Denpasar. Hal ini bertujuan agar makan yang telah selesai kita masak dan yang akan kita konsumsi mendapat anugerah dari Tuhan, sehingga bermanfaat positif bagi fisik, mental, dan spiritual.

Beberapa aturan dalam budaya makan akan memastikan bahwa makanan yang dimakan berpengaruh optimal secara fisik, mental, dan spiritual. Aturan makan yang dimaksud sebagai berikut.

(1) Membersihan diri (mandi atau mencuci tangan) sebelum makan dan berdoa.

(2) Duduk dengan nyaman pada saat makan.

(3) Makan makanan yang masih segar, dan mengandung berbagai zat gizi yang diperlukan tubuh seperti karbohidrat, protein, vitamin, lemak, dan mineral.

(4) Makan bersama. Bersantap dengan gembira bersama kawan maupun keluarga akan memberikan kebahagiaan dalam diri.

(5) Makan dalam kondisi pikiran yang tenteram.

(6) Makan dengan perlahan dan kunyah makanan sampai hancur.

(7) Makanlah pada saat lapar, agar apa yang dimakan benar-benar memberikan manfaat yang optimal.

(8) Makan dalam jumlah yang cukup (tidak berlebihan).

(9) Beristirahat setelah makan. Setelah makan dianjurkan untuk beristirahat sekitar 10-15 menit. Hal ini akan membantu proses pencernaan dan mengurai efek samping yang tidak menyenangkan karena makan dengan tergesa-gesa.

(10) Makan pada jam-jam teratur. Hindari makan sebelum tidur, karena dapat menyebabkan proses pencernaan tidak berjalan dengan baik dan dapat memicu timbulnya penyakit.

(11) Jangan minum selama makan. Jika kita minum air pada saat makan, maka kerja air liur yang berfungsi untuk proses pencernaan tidak akan bekerja dengan baik (Shiilabhadrananda, 2010: 21-24).

Makanan yang akan dikonsumsi hendaknya dipersembahkan terlebih dahulu kepada Tuhan. Dalam Bhagawadgita III.13 (Pudja, 1997: 78) disebutkan sebagai berikut:

Yadnya sistasinah santo 


\section{Pola Konsumsi Makanan Satwika Pada Bhakta}

Di Sri Sri Krishna Balarama Ashram

\section{Gede Sutana}

muchyante sarva kalbishaih

bhunjate te ty agham papa

ye pachanty atma karanat

Terjemahan:

Ia yang makan makanan yang telah dipersembahkan kepada Tuhan

akan terlepas dari segala dosa

(tetapi) Ia yang hanya memasak makanan

Hanya bagi diri sendiri, sesungguhnya makan dosa

Satvic (2007:50-54) menyatakan bahwa makanan dengan kombinasi yang baik akan berada di perut sekitar tiga jam. Makanan dengan kombinasi tidak baik akan berada dalam perut sekitar dua belas jam. Dengan demikian, mengkonsumsi makanan paling baik dilakukan antara pukul 12.00 sampai pukul 14.00 untuk makan siang, sedangkan untuk makan sore/malam dilakukan pada pukul 17.00 sampai dengan pukul 19.00. Jeda atau jarak waktu antara makan siang dan makan sore/malam yang baik adalah sekitar lima jam.

Berkenaan dengan hal di atas dapat diketahui bahwa hal-hal detail dari cara memperoleh bahan makanan, pemilihan bahan makanan, hingga tata cara menghidangkan dan mengkonsumsi makanan satwika di Sri Sri Krishna Balarama Ashram merupakan satu kesatuan yang tidak dapat dipisahkan satu sama lainnya karena ketika salah satu proses ini dipisahkan maka secara fungsional akan mempengaruhi pola konsumsi makanan satwika itu sendiri.

\section{Implikasi Pola Konsumsi Makanan Satwika Terhadap Bhakta di Sri Sri Krishna Balarama Ashram Denpasar}

Menerapkan pola konsumsi makanan satwika sesuai aturan dapat memberikan implikasi terhadap bhakta yang mengkonsumsinya. Implikasi yang dirasakan oleh bhakta di Sri Sri Krishna Balarama Ashram tidak hanya implikasi secara spiritual, tetapi juga secara fisik dan mental. Fisik, mental, dan spiritual, ketiganya saling mendukung untuk untuk mencapai kesehatan yang holistik.

Makanan memerankan peran yang sangat penting dalam menentukan pikiran, perbuatan, perasaan, dan perkataan seseorang. Makanan dikelompokka berdasarkan kandungan tri guna-nya menjadi tiga: satwika, rajasika, dan tamasika. Kendalikanlah tubuh dan inderamu, kendalikanlah pikiranmu, makanlah dalam jumlah yang cukup dan milikilah 


\section{Pola Konsumsi Makanan Satwika Pada Bhakta}

Di Sri Sri Krishna Balarama Ashram

\section{Gede Sutana}

umur yang panjang. Makanlah hanya makanan satwika, karena makanan ini baik untuk spiritual dan kesadaran diri. Makan yang secukupnya dan satwika sangatlah penting untuk kemajuan spiritual. Latihan spiritual (sadhana) tidak akan mendatangkan hasil terkecuali engkau mengubah kebiasaan makanmu. Semua orang yang ingin meningkatkan spiritual haruslah mengkonsumsi makanan satwika (Satvic, 2007: 14-26).

Mengkonsumsi makanan bukanlah sekedar untuk memenuhi kebutuhan akan zat gizi untuk tubuh, tetapi juga untuk makanan yang sehat secara spiritual. Makanan memiliki hubungan langsung dan sangat erat dengan pikiran dan memiliki peran yang sangat penting dalam membentuk pikiran, maka milikilah pikiran yang satwika. Darmayasa (1997: 37) mengatakan bahwa "you are what you eat" dengan kata lain "anda adalah apa yang anda makan". Bagaimana jenis pengaturan makanan begitulah jadinya kita. Para Rsi dan Brahmana terkenal sebagai golongan cerdas. Beliau selalu mengatur makanan satwam-nya untuk meningkatkan sifat satwam-nya. Demikian pentingnya pengaturan makanan jenis satwam, yang dibenarkan pula oleh kitab suci Chandogya Upanisad VII-XXVI-2

\section{Ahara suddhau satta suddhih \\ Sattva suddhau dhruva smrtih \\ Smrti lambhe sarvagrathinam Vipra moksah}

\section{Artinya:}

Ketika makanan yang dimakan murni, maka seluruh sifat menjadi murni, ketika sifat menjadi murni maka ingatan akan menjadi kokoh (tajam) dan jika seseorang telah memiliki ingatan yang kokoh (tajam), maka semua ikatan duniawi akan terputuskan (moksa).

Dalam Bhagawadgita (Suhardana, 2010: 36-37) disebutkan sebagai berikut:

$$
\begin{aligned}
& \text { Ayuh - sattva - balarogya- } \\
& \text { Sukha - priti-vivardhanah, } \\
& \text { Rasyah snigdhah sthira hrdya } \\
& \text { Aharah sattvika - priyah }
\end{aligned}
$$

Artinya:

(Bhagawadgita XVII.8)

Makanan yang memperpanjang hidup, memberikan tenaga, kekuatan, kesehatan, kebahagiaan, suka cita, makanan yang rasanya manis, lunak, mengandung berbagai 


\section{Pola Konsumsi Makanan Satwika Pada Bhakta}

Di Sri Sri Krishna Balarama Ashram

\section{Gede Sutana}

zat makanan dan rasanya enak adalah makanan satwika yang disukai (dikonsumsi) oleh orang yang bersifat satwam. Kesucian dan kemurnian makanan dapat menyehatkan pikiran. Jika pikiran sehat, maka semua metabolisme di dalam tubuh akan dapat terkontrol dan berjalan dengan baik sehingga tubuh tetap sehat

Dikatakan bahwa tidak mengkonsumsi daging termasuk pengendalian diri, pengendalian lidah, demikian juga melakukan puasa, rasa kasih sayang terhadap semua makhluk, itulah prinsip sehat spiritual secara universal. Hal ini akan mempengaruhi sehat jasmani dan sehat rohani. Pola makan satwika mendorong pengembangan kesadaran perdamaian, kasih sayang, dan spiritual. Asupan makanan satwika membantu dalam pengembangan prana dan kesadaran spiritual (Wijaya, 2009: 61).

Menurut ilmu Ayurweda dikatakan bahwa makanan satwika merupakan makanan yang dapat menambah sifat bijaksana, sabar serta mampu menjaga keseimbangan unsur tri dosha dalam tubuh. Mengkonsumsi makanan satwika dapat memperpanjang usia, menyucikan pikiran, menguatkan tubuh, menyehatkan tubuh, membuat bahagia, dan meningkatkan kualitas hidup. Dengan cara mengkonsumsi makanan satwika disertai penyajiannya memuaskan panca indria, sehingga baik raga sarira maupun suksma sarira terpuaskan, dengan demikian kedua sarira ini dapat berfungsi secara optimal, menjadikan tubuh tetap svasthya (sehat) (Nala, 2001: 97-98).

Prof. Benhard Watzi dari Institute of Nutrional Psysiology Karishure Jerman dalam Almatsier (2002:12), keunggulan makanan yang berjenis vegetarian berkaitan dengan senyawa yang dikandungnya, khususnya senyawa bioaktif yang mempunyai efek kesehatan, dan dikenal sebagai fitokimia. Fitokimia terdiri dari karotenoid, fitosteral, saponin, polifenol, protease inhibitors, dan fitoestrogen sulfida.

Mereka yang mengkonsumsi makanan yang bersumber dari bahan pangan nabati terhimpun dalam suatu organisasi Indonesia Vegetarian Society (IVS) dan Vegan Society of Indonesia (VSI). Setelah melakoninya dalam waktu yang cukup, mereka dapat merasakan manfaatnya. Manfaat yang dirasakan, yaitu di samping kesehatan fisik juga berkaitan dengan nonfisik. Mereka merasakan hidupnya lebih senang, emosi lebih stabil, pikirannya menjadi lebih tenang, dan merasakan lebih damai (Susianto, 2014: 155). 


\section{Pola Konsumsi Makanan Satwika Pada Bhakta}

Di Sri Sri Krishna Balarama Ashram

\section{Gede Sutana}

Begitu besar pengaruh makanan terhadap mental dan tingkah laku seseorang, makanan bukan hanya urusan perut belaka. Makanan juga mempunyai pengaruh terhadap perilaku seseorang. Pikiran dan karakter terbentuk, tersusun atas makanan yang kita makan. Energi satwika dalam makanan menyebabkan munculnya kesadaran terhadap diri sendiri, rasa kasih sayang, kedamaian, kesucian, dan kebahagiaan. Apalagi energi satwika mendominasi pikiran, seseorang akan merasakan kedamaian dan ketentraman dalam dirinya. Makanan satwika merupakan makanan yang menjadi dasar diet para yogi, bagi mereka yang ingin meningkatkan kesadaran jiwanya ke tingkat lebih tinggi untuk mencapai kesejatian dirinya (Anandamitra, 1990: 3).

Seorang bhakta harus belajar untuk mengendalikan pikiran secara benar dan gunakanlah makanan satwika untuk memberi energi satwika pada pikiran. Makanan satwika adalah makanan yang didominasi oleh sifat satwam, dimana jika dikonsumsi akan memberikan suatu efek positif terhadap pikiran. Makanan satwika sangat penting bagi seorang bhakta karena sangat menunjang usaha untuk melakukan pembersihan jasmani maupun rohani. Makanan satwika merupakan makanan yang menjadi dasar diet para yogi atau bhakta yang ingin meningkatkan kesadaran jiwanya ke tingkat lebih tinggi untuk mencapai kesejatian dirinya.

\section{Simpulan}

Dalam menerapkan pola konsumsi makanan satwika, ada tiga hal yang mendorong bhakta di Sri Sri Krishna Balarama Ashram Denpasar, diantaranya: aturan, pilihan rasional, dan fungsional dari pola konsumsi makanan satwika tersebut. Ketiga hal ini saling keterkaitan satu sama lain. Aturan merupakan hal utama yang mendorong bhakta menerapkan pola konsumsi makanan satwika. Bhakta di Sri Sri Krishna Balarama Ashram Denpasar taat kepada aturan pola konsumsi makanan satwika karena dengan menaati aturan membuat hidup bhakta di Sri Sri Krishna Balarama Ashram lebih teratur, khususnya dalam hal mengkonsumsi makanan. Selain aturan, pilihan rasional juga mendasari bhakta dalam menerapkan pola konsumsi makanan satwika. Secara rasional, bhakta di Sri Sri Krishna Balarama Ashram meyakini makanan satwika memiliki manfaat yang lebih baik dari pada 


\section{Pola Konsumsi Makanan Satwika Pada Bhakta}

Di Sri Sri Krishna Balarama Ashram

\section{Gede Sutana}

jenis makanan lainnya. Disamping itu, karena harga bahan makanan satwika lebih murah dari bahan makanan yang mengandung daging dianggap dapat menghemat pengeluaran bhakta dalam membeli makanan. Secara fungsional makanan satwika baik bagi fisik, mental, dan spiritual juga mendorong bhakta di Sri Sri Krishna Balarama Ashram Denpasar untuk menerapkan pola konsumsi makanan satwika. Pola konsumsi makanan satwika di Sri Sri Krishna Balarama Ashram Denpasar meliputi lima komponen yang merupakan satu kesatuan yang tidak dapat dipisahakan satu dengan lainnya. Kelima komponen tersebut, diantaranya: (a) cara memperoleh bahan makanan satwika, (b) jenis bahan makanan satwika, (c) menu makanan satwika, (d) cara mengolah makanan satwika, dan (e) cara menghidangkan dan mengkonsumsi makanan satwika. Dengan menerapkan pola konsumsi makanan satwika sesuai aturan diyakini dapat memberikan implikasi terhadap bhakta yang mengkonsumsinya. Implikasi yang dirasakan oleh bhakta di Sri Sri Krishna Balarama Ashram Denpasar tidak hanya berimplikasi secara spiritual, tetapi juga secara fisik dan mental. Fisik, mental, dan spiritual, ketiganya saling mendukung untuk untuk mencapai hidup yang sehat.

\section{Daftar Pustaka}

Acarya, A.A. (2005). Food For Thought The Vegetarian Philosophy. Third Edition. Jakarta: Ananda Marga Publications.

Almatsier, Sunita. (2002). Prinsip Dasar Ilmu Gizi. Jakarta: Gramedia Pustaka Utama.

Anandamitra, Avadhutika Acarya. (1990). Yoga Untuk Kesehatan, Latihan Yoga Ananda Marga. Jakarta: Persatuan Ananda Marga Indonesia.

Budiyasa, Gede Ngurah. (2016). Makanan Satwika dan Profil Lipid Pada Bhakta Sai Denpasar. Disertasi. Denpasar: UNHI Denpasar.

Darmayasa. (1997). Ahimsa Dharma \& Vegetarian. Surabaya: Paramita.

Fracassi, Clotilde dan Paul Urbani. (2001). Kasih Sayang dan Restu Sri Satya Sai. Jakarta: Yayasan Sri Satya Sai Indonesia.

ISKCON. (2006). Penuntun Bhakti Kepribadian Tertinggi Tuhan Sri Krishna. Denpasar: Organisasi Kerohanian Hindu ISKCON Indonesia.

Kariadi, S.H.K.S. (2009). Diabetes? Siapa Takut. Edisi Pertama. Bandung: Gramedia. Kurniajaya, Made. (2013). Eksistensi Makanan Satwika di Sai Pooja Ashram Kelurahan Padang Sambian Denpasar. Skripsi. Denpasar: IHDN Denpasar.

Kusuma, Ni Made Wahyuni Putri. (2012). Pengembangan Kecerdasan Spiritual Melalui Astangga Yoga di Ashram Ananda Marga Denpasar. Tesis. Denpasar: IHDN Denpasar.

Maysuhara, S. (2009). Rahasia Cantik, Sehat, dan Awet Muda. Edisi Pertama. Yogyakarta: Pustaka Panasea.

Satya Widya : Jurnal Studi Agama Vol. 3 No. 22020

DOI: https://doi.org/10.33363/swjsa.v3i2.477 


\section{Pola Konsumsi Makanan Satwika Pada Bhakta}

Di Sri Sri Krishna Balarama Ashram

\section{Gede Sutana}

Nala, Ngurah. (2001). Ayurveda Ilmu Kedokteran Hindu 1. Denpasar: Upada Sastra. Prima, Surya Wijaya. (2009). Makanan Satwik Dan Kesehatan. Surabaya: Paramita. Pudja, Rai Sudharta. (1997). Bhagawadgita (Pancama Weda). Jakarta: Hanuman Sakti. Radhakrisna, S. (2009). Bhagawad Gita. Edisi Pertama. Yogyakarta: IRCiSoD.

Satvic, Gerard T. (2007). Awet Muda Dan Panjang Umur Dengan Ayurveda. Surabaya: Paramita.

Suhardana, Komang. (2010). Ahimsa Dan Vegetarian Jalan Menuju Kasih Sayang. Surabaya: Paramita.

Susenas. (2010). Hasil Survei Sosial Ekonomi Nasional Tahun 2010. Jakarta: Bapan Pusat Statistik.

Susianto. (2014). Vegan Itu Mudah. Jakarta: Mizan Publika.

Widuri, Hesti. (2013). Komponen Gizi Dan Bahan Makanan Untuk Kesehatan. Yogyakarta: Pustaka Baru.

Wibawa, Made Aripta. (2012). Makanan Sumber Malapetaka, Konflik, dan Penyakit. Denpasar: Pustaka Balipost.

Wijaya, A.A Ngurah Prima. (2009). Makanan Satwik \& Kesehatan: Konsep Hidup Masa Lalu Untuk Solusi Kesehatan dan Pengembangan Spiritual di Jaman Modern. Surabaya: Paramita. 